\title{
The Business Cycle And The Portfolio Composition Of Mutual Funds
}

https://doi.org/10.21272/sec.4(2).5-13.2020

Halil D. Kaya, ORCID: https://orcid.org/0000-0002-7535-9857

$\mathrm{PhD}$, Professor of Finance, Department of Accounting and Finance, College of Business and Technology, Northeastern State University, USA

Julia S. Kwok, ORCID: https://orcid.org/0000-0002-1321-2200

$\mathrm{PhD}$, Professor of Finance, Department of Accounting and Finance, College of Business and Technology, Northeastern State University, USA

\begin{abstract}
This paper summarizes the arguments and counterarguments within the scientific discussion on the issue of mutual funds' composition across the business cycle. The main purpose of the research is to determine whether mutual funds alter their investments across the business cycle. Systematization of the literary sources and approaches for solving the problem of the relationship between the business cycle and the composition of mutual funds indicates that five-star rated mutual funds may have an investment strategy that is different from lower-rated funds. Investigation of the topic of the relationship between the business cycle and composition of mutual funds in the paper is carried out in the following logical sequence: First, we classified each quarter as an "improving" or a "worsening" business condition period based on the Aruoba-Diebold-Scotti Business Conditions Index. As a result, we had seven "improving" and seven "worsening" business condition periods during our sample period. Then, we compared each star-group's (one-star to five-star) investments in common stocks, preferred stocks, convertible bonds, warrants, corporate bonds, municipal bonds, government bonds, other securities, and cash across the "improving" versus the "worsening" periods. The methodological tools utilized in this research were nonparametric tests. The objects of the research are the mutual funds listed in the CRSP quarterly mutual funds dataset for the 2003-2006 period. The paper presents the results of an empirical analysis for these mutual funds, which showed that five-star funds tend to have a different strategy when compared to lower-rated funds. The research empirically confirms and theoretically proves that the fivestar funds tend to invest more in riskier assets and they tend to better adjust to the conditions (i.e. invest more in common stocks and less in bonds in improving periods) when compared to the other groups. This explains their success: higher NAVs compared to the other groups and higher star ratings. On the other hand, our results show that the lower-rated funds do not adjust their investments in main asset classes like stock and bonds during "improving" versus "worsening" business condition periods. Overall, our results indicate that mutual funds' star ratings and NAVs are linked to these funds' success in their adaptation to the macro-economic environment. The results of the research can be useful for investment firms or individual investors that consider investing in U.S. mutual funds.
\end{abstract}

Keywords: mutual fund, portfolio, business cycle, recession, net asset value.

JEL Classification: G11, G23.

This work is licensed under a Creative Commons Attribution 4.0 International License.

Cite as: Kaya, H.D., Kwok, J.S. (2020). The Business Cycle And The Portfolio Composition Of Mutual Funds? SocioEconomic Challenges, 4(2), 5-13. https://doi.org/10.21272/sec.4(2).5-13.2020.

(C) The Authors, 2020. This article is published with open access at Sumy State University.

\section{Introduction}

In this paper, our objective is to examine the 1-star through 5-star mutual fund groups' general investment compositions. We also want to examine how each group reacts to business conditions.

In order to differentiate between "improving" and "worsening" business conditions, we use the AruobaDiebold Scotti Business Conditions Index. The Federal Reserve Bank of Philadelphia calculates the ADS 
index each day. The ADS Index is a continuous index that tracks real business conditions at high frequency. It tracks economic indicators like weekly initial jobless claims, monthly payroll employment, industrial production, personal income less transfer payments, manufacturing and trade sales, and quarterly real GDP in real time. The daily values of the index are posted on Philadelphia Fed's website.

We create a dummy variable called "Improving" which is equal to one if the ADS Business Conditions Index had gone up compared to the last quarter, and equal to zero if the index had gone down compared to the last quarter. Our sample period is from the third quarter of 2003 through the fourth quarter of 2006. The period covers fourteen periods in total. Looking at the ADS Business Conditions Index, seven quarters are classified as "improving" and seven as "worsening".

Using nonparametric tests, we compare each star group's investments in "improving" versus worsening" periods. We show in detail how star ratings are related to the general investment composition of the funds as well as to the funds' behavior across Improving and Worsening Business condition periods.

We find that the 5-star funds tend to invest more in riskier assets and they tend to better adjust to the conditions (i.e. invest more in common stocks and less in bonds in improving periods) when compared to the other groups. This explains their success: higher NAVs and higher star ratings compared to the other groups.

Our paper proceeds as follows: Section 2 goes over the previous literature. Section 3 explains the data and the methodology. Section 4 shows the empirical results. Section 5 concludes.

\section{Literature Review}

There are two streams of research: One deals with the relationship between the business cycle and the funds flows to or from a mutual fund. For example, Cederburg (2008) and Glode et al. (2005) show that there is generally increased cash flows during expansions and reduced cash flows during contractions. Jank (2012) argues that mutual fund flows are forward-looking (i.e. predict future economic activity). According to the author, variables that predict the real economy and/or equity premium (i.e. dividend-price ratio, default spread, relative T-Bill rate, and consumption-wealth ratio) explain mutual fund flows. The other stream of research deals with the relationship between the business cycle and the performance of mutual funds (Bello (2008), Lynch et al. (2002), Fink, Raatz, and Weigert (2015)). In this current paper, we contribute to the literature on the relationship between the business cycle and the performance of mutual funds.

Most of the previous research (Bello (2008) and Lynch et al. (2002)) shows that, during economic expansions, the mutual fund market as a whole tend to underperform when compared to the overall market. The opposite is true during recessionary periods. During recessionary periods, mutual funds on average tend to do better than the market. While these are true for the mutual fund sector as a whole, the success of an individual fund varies. The success of a fund depends on its ability to adopt to the macro environment, and this is generally linked to the skill level of the fund manager. Several previous studies (Cici (2010), Brinson, Hood and Beebower (1995), (Carhart, 1997), Kacperczyk, Van Nieuwerburgh and Veldkamp (2016), and Kosowksi (2011)) focus on fund manager's skill set. Most of these papers emphasize the importance of the manager's skill set (i.e. except for Carhart (1997)) on the performance of a mutual fund.

Cici (2010) argues that the declining liquidity in the sector during recessionary periods hurts the performance of the funds. Also, during these periods, managers tend to act irrationally by buying more losers and selling more winners. According to the author, the time pressure for the managers during these periods also exacerbates their irrational behaviour. Brinson, Hood and Beebower (1995) examine how managers' investment policy, timing, and selection affect the funds' performance. They show that their investment policy is very important for the funds' success. Kacperczyk, Van Nieuwerburgh and Veldkamp (2016) argue that a manager's skill set as well as his/her attention span are important. During recessionary periods, paying attention to asset allocation is important. Kacperczyk, Van Nieuwerburgh and Veldkamp (2014) show that, for fund managers, while stock picking is more prevalent in booms, market timing dominates in recessions. They develop a model and show that some managers are skilled. These managers can significantly outperform the market. According to Kosowksi (2011), a manager's skill set with respect to information gathering, stock selection and market timing with respect to the different phases of the cycle is important.

Several papers compare the performance of actively-managed funds to the performance of index funds while taking the business cycle into consideration. Wermers (2000) shows that actively-managed funds, on average, generate an additional $6 \%$ per year during recessions versus expansions. Avramov and Wermers (2006) show 
that actively managed funds do especially well during recessionary periods (i.e. compared to the index funds and also compared to the same actively-managed funds during expansions). They argue that this is due to the fund manager's ability to choose the correct investments across the business cycle. Avramov (2004) shows that incorporating macroeconomic variables when investing in portfolios is profitable. Avramov and Chordia (2005) does the same for individual stocks. Kandel and Stambaugh (1996) show that the current values of the business cycle variables are important when choosing the best equity versus cash level for investors. Fortin and Michelson (2002) show that, on average, index funds perform better than actively-managed funds with the exception of the contraction periods. Glode (2011) shows that, in good times, actively managed funds underperform the market, and in bad times, they outperform the market.

In this current paper, we first focus on the investments of our sample funds across the business cycle. Does the portfolio composition of the funds change significantly across the business cycle? For example, do funds have more money in common stocks during good times? Or do they reduce their cash holdings or bond investments during these times? We will compare the portfolio weights of these funds in different asset classes during improving business condition periods to those during worsening business condition periods. When doing our comparisons, we will do a separate analysis for each star-group. How do the 5-star funds change their investments when conditions change? How do the 1-, 2-, 3-, or 4-star funds change their investments? Are the 5 -star funds which are deemed as the most successful funds better in adapting to the macro conditions when compared to the less successful funds? We would expect the 5-star funds to be more successful in changing their investments when times change, and this would be a reflection of the fund manager's skill level.

In this paper, we also look at how the Net Asset Values change for each star group across the business cycle. We expect to see the 5-star group to be more successful in adapting to the macro environment (i.e. in matching their investments with the macro environment). In other words, we expect them to increase their investments in riskier assets (like common stocks) during improving periods, and to increase their bond holdings and cash during worsening periods. If they correctly match their investments with the macro environment, they should see an increase in their values during good times. On the other hand, we expect to see the other star groups to be less successful in matching their investments with the macro environment (i.e. this may be due to the skill level of the manager or due to other reasons). If they do not correctly match their investments with the macro environment, they may not be able to see an increase in their values during good times.

In the next section, we will explain our data and methodology.

\section{Data and Methodology}

We use the quarterly mutual funds data from CRSP Mutual fund database. Our sample period is from the end of the second quarter of 2003 through the end of 2006.

Our first objective in this paper is to examine each star-group's general investment composition. Table 1 shows the summary statistics. Among the five groups of star ratings, the 5-star funds' investment in risky assets like common stocks and preferred stocks is the highest. For this group (i.e. 5-star group), 57.15\% of the investments are in common stocks (while for other star-groups, this number ranges from $50.06 \%$ to $52.61 \%$ ). Again, for the 5-star group, $0.47 \%$ of the assets are in preferred shares (while for other star-groups, this number ranges from $0.25 \%$ to $0.41 \%$ ).

Table 1. Summary Statistics

\begin{tabular}{|l|c|c|c|c|c|c|c|c|c|c|}
\hline & \multicolumn{2}{|c|}{ 1-star } & \multicolumn{2}{c|}{ 2-star } & \multicolumn{2}{c|}{ 3-star } & \multicolumn{2}{c|}{ 4-star } & \multicolumn{2}{c|}{ 5-star } \\
\hline & Mean & Std & Mean & Std & Mean & Std & Mean & Std & Mean & Std \\
\hline \% common stocks & 51.88 & 47.15 & 52.61 & 46.88 & 50.06 & 47.12 & 50.43 & 46.60 & 57.15 & 44.91 \\
\hline \% preferred stocks & 0.36 & 2.64 & 0.25 & 1.77 & 0.25 & 1.77 & 0.41 & 2.77 & 0.47 & 2.45 \\
\hline \% convertible bonds & 0.33 & 4.32 & 0.35 & 4.41 & 0.31 & 4.04 & 0.45 & 5.03 & 0.37 & 3.72 \\
\hline \% warrants & 0.03 & 0.23 & 0.02 & 0.21 & 0.02 & 0.21 & 0.03 & 0.31 & 0.03 & 0.27 \\
\hline \% corporate bonds & 7.48 & 20.38 & 7.49 & 20.27 & 6.95 & 19.45 & 9.40 & 22.52 & 7.95 & 20.19 \\
\hline \% municipal bonds & 12.32 & 32.51 & 12.40 & 32.64 & 11.25 & 31.32 & 16.29 & 37.33 & 10.83 & 30.93 \\
\hline \% government bonds & 8.20 & 21.51 & 7.93 & 20.93 & 7.38 & 20.27 & 7.75 & 19.90 & 6.62 & 18.36 \\
\hline \% other securities & 3.15 & 19.63 & 4.80 & 20.51 & 5.81 & 22.63 & 7.11 & 26.46 & 7.87 & 26.87 \\
\hline \% cash & 16.07 & 34.00 & 13.94 & 30.42 & 17.77 & 34.55 & 7.91 & 19.80 & 8.48 & 19.21 \\
\hline NAV & 11.99 & 9.71 & 12.67 & 10.04 & 13.21 & 13.40 & 15.89 & 13.08 & 17.84 & 15.96 \\
\hline
\end{tabular}

Source: Authors' own work. 
Among the five groups, the 5-star funds' investment in the least risky assets like government bonds is the lowest, which is $6.62 \%$ (while the other groups range from $7.38 \%$ to $8.20 \%$ ). In terms of cash, the 5-star group has $8.48 \%$ of its assets in cash, while other groups range from $7.91 \%$ to $17.77 \%$.

In terms of convertible bonds and corporate bonds, the 5-star funds have the second highest investment after the 4-star funds. The 5-star funds have, on average, $0.37 \%$ of their assets in convertible bonds (only 4-star funds hold more at $0.45 \%$; other groups range from $0.31 \%$ to $0.35 \%$ ). The 5 -star funds have, on average, $7.95 \%$ of their assets in corporate bonds (only 4 -star funds hold more at $9.40 \%$; other groups range from $6.95 \%$ to $7.49 \%)$.

In terms of municipal bonds, the 4-star group has the biggest investment. The 4-star funds, on average, have $16.29 \%$ of their assets in municipal bonds (versus $10.83 \%$ for the 5 -star group). The other groups range from $11.25 \%$ to $12.40 \%$.

What is the difference between the 4-star and the 5-star fund groups? The two groups are similar in their investments except for the following: The 5-star funds generally invest more in common and preferred stocks. The 4-star funds invest more in bonds (convertible, corporate, municipal, and government bonds).

When we look at the Net Asset Values (i.e. NAVs), we see a gradual increase with the star rating: 1-star funds' mean NAV is $\$ 11.99$. The corresponding values are $\$ 12.67, \$ 13.21$, and $\$ 15.89$ for the 2-, 3-, and 4-star groups. The 5-star group has the highest mean NAV with a value of $\$ 17.84$.

After examining how investments differ across the five star-groups, we want to examine how each group reacts to business conditions. As a measure of the business conditions in the United States, we use the AruobaDiebold Scotti Business Conditions Index (the ADS Index). The Federal Reserve Bank of Philadelphia calculates the daily value of the ADS index each day and posts it on its website. The ADS Index is a continuous index that tracks real business conditions at high frequency. It tracks economic indicators like weekly initial jobless claims, monthly payroll employment, industrial production, personal income less transfer payments, manufacturing and trade sales, and quarterly real GDP in real time.

We create a dummy variable called "Improving" which is equal to one if the ADS Business Conditions Index had gone up compared to the last quarter, and equal to zero if the index had gone down compared to the last quarter.

Table 2 shows whether the business conditions improved in each quarter in our sample period (from the $3^{\text {rd }}$ quarter of 2003 through the $4^{\text {th }}$ quarter of 2006). There are 14 quarters in total over our sample period. Looking at the ADS Business Conditions Index, seven quarters are classified as "Improving" and seven are classified as "Worsening".

Table 2. Improving vs. Worsening Business Conditions

\begin{tabular}{|c|c|c|c|}
\hline Year & Quarter & Improving & Worsening \\
\hline 2003 & 3 & 1 & 1 \\
\hline 2003 & 4 & 0 & 0 \\
\hline 2004 & 1 & 1 & 1 \\
\hline 2004 & 2 & 0 & 0 \\
\hline 2004 & 3 & 1 & 0 \\
\hline 2004 & 4 & 1 & 0 \\
\hline 2005 & 1 & 0 & 1 \\
\hline 2005 & 2 & 1 & 0 \\
\hline 2005 & 3 & 0 & 1 \\
\hline 2005 & 4 & 1 & 1 \\
\hline 2006 & 1 & 0 & 1 \\
\hline 2006 & 2 & 0 & 0 \\
\hline 2006 & 3 & 0 & \\
\hline 2006 & 4 & 1 & \\
\hline
\end{tabular}

Source: Authors' own work.

In our empirical analysis, first we will compare the investments of each star group across the improving versus worsening business condition periods. For example, on average, what percent of the one-star funds' money went to common stocks? What percent went to preferred shares? What percent went to corporate bonds? What percent was held as cash? Similarly, what percent of the two-star, three-star, four-star, or five-star funds' money went to each asset class? We will do these comparisons using non-parametric tests (i.e. Mann-Whitney- 
Wilcoxon tests). Then, we will compare the Net Asset Values of each star group across the improving versus worsening business condition periods. For example, what are the NAVs of the one-star funds during the improving condition periods? What are the NAVs of these funds during the worsening periods? Similarly, what are the NAVs of the two-star, three-star, four-star, or five-star funds during the improving condition periods? What are the NAVs of these funds during the worsening periods? Again we will use the MannWhitney-Wilcoxon tests for these comparisons.

\section{Empirical Results}

First, we compare each star-group's investments across the "Improving" versus the "Worsening" business condition periods. These comparisons are shown in Table 3. The last column shows the results of the Mann Whitney Wilcoxon test.

Table 3. Investments in Improving vs. Worsening Periods

\begin{tabular}{|c|c|c|c|c|}
\hline & & Improving & Worsening & Wilcoxon \\
\hline & & Mean & Mean & p-value \\
\hline \multirow[t]{9}{*}{ 1-star } & $\%$ invested in common stocks & 51.955 & 51.801 & 0.3191 \\
\hline & $\%$ invested in preferred stocks & 0.364 & 0.358 & 0.0351 \\
\hline & $\%$ invested in convertible bonds & 0.316 & 0.341 & 0.2268 \\
\hline & $\%$ invested in warrants & 0.033 & 0.021 & 0.0002 \\
\hline & $\%$ invested in corporate bonds & 7.606 & 7.366 & 0.9927 \\
\hline & $\%$ invested in municipal bonds & 12.471 & 12.183 & 0.1561 \\
\hline & $\%$ invested in government bonds & 8.067 & 8.326 & 0.8286 \\
\hline & $\%$ invested in other securities & 3.290 & 3.013 & 0.8679 \\
\hline & $\%$ invested in cash & 15.708 & 16.411 & 0.0002 \\
\hline \multirow[t]{9}{*}{ 2-star } & $\%$ invested in common stocks & 52.528 & 52.694 & 0.2954 \\
\hline & $\%$ invested in preferred stocks & 0.261 & 0.245 & 0.0176 \\
\hline & $\%$ invested in convertible bonds & 0.346 & 0.361 & 0.5688 \\
\hline & $\%$ invested in warrants & 0.023 & 0.022 & 0.2695 \\
\hline & $\%$ invested in corporate bonds & 7.572 & 7.420 & 0.1077 \\
\hline & $\%$ invested in municipal bonds & 12.551 & 12.247 & 0.0704 \\
\hline & $\%$ invested in government bonds & 7.916 & 7.937 & 0.2594 \\
\hline & $\%$ invested in other securities & 4.407 & 5.172 & 0.1338 \\
\hline & $\%$ invested in cash & 14.158 & 13.726 & 0.5213 \\
\hline \multirow{9}{*}{ 3-star } & $\%$ invested in common stocks & 50.834 & 49.284 & $<0.0001$ \\
\hline & $\%$ invested in preferred stocks & 0.248 & 0.249 & 0.2212 \\
\hline & $\%$ invested in convertible bonds & 0.305 & 0.317 & 0.6440 \\
\hline & $\%$ invested in warrants & 0.022 & 0.017 & 0.0622 \\
\hline & $\%$ invested in corporate bonds & 6.882 & 7.017 & 0.0458 \\
\hline & $\%$ invested in municipal bonds & 11.131 & 11.372 & 0.2660 \\
\hline & $\%$ invested in government bonds & 7.091 & 7.671 & 0.0851 \\
\hline & $\%$ invested in other securities & 5.435 & 6.193 & 0.9626 \\
\hline & $\%$ invested in cash & 17.881 & 17.663 & 0.3197 \\
\hline \multirow[t]{9}{*}{ 4-star } & $\%$ invested in common stocks & 47.910 & 52.720 & $<0.0001$ \\
\hline & $\%$ invested in preferred stocks & 0.434 & 0.389 & 0.7792 \\
\hline & $\%$ invested in convertible bonds & 0.458 & 0.452 & 0.1711 \\
\hline & $\%$ invested in warrants & 0.031 & 0.026 & 0.0491 \\
\hline & $\%$ invested in corporate bonds & 10.046 & 8.808 & $<0.0001$ \\
\hline & $\%$ invested in municipal bonds & 17.908 & 14.821 & $<0.0001$ \\
\hline & $\%$ invested in government bonds & 8.562 & 7.002 & $<0.0001$ \\
\hline & $\%$ invested in other securities & 6.215 & 7.919 & $<0.0001$ \\
\hline & $\%$ invested in cash & 8.234 & 7.624 & 0.0039 \\
\hline \multirow[t]{9}{*}{ 5-star } & $\%$ invested in common stocks & 59.538 & 55.049 & $<0.0001$ \\
\hline & $\%$ invested in preferred stocks & 0.499 & 0.439 & 0.3005 \\
\hline & $\%$ invested in convertible bonds & 0.358 & 0.376 & 0.6205 \\
\hline & $\%$ invested in warrants & 0.030 & 0.026 & 0.0858 \\
\hline & $\%$ invested in corporate bonds & 7.933 & 7.961 & 0.0049 \\
\hline & $\%$ invested in municipal bonds & 9.455 & 12.038 & $<0.0001$ \\
\hline & $\%$ invested in government bonds & 6.948 & 6.335 & 0.1513 \\
\hline & $\%$ invested in other securities & 7.553 & 8.148 & 0.5819 \\
\hline & $\%$ invested in cash & 7.343 & 9.481 & 0.5243 \\
\hline
\end{tabular}

Source: Authors' own work. 
The results show that the 4-star group is the most aggressive group among the five groups. This group changes its investments across improving and worsening periods in 7 out of 9 asset classes (p-value $<0.10$ in 7 asset classes). When business conditions are improving, the group invests less in common stocks and other securities and more in corporate, municipal, government bonds, and warrants. They also hold more cash during these periods. This shows that this group of funds are following a contrarian strategy because, in improving periods, they invest less in risky assets like common stocks and more in less risky assets like corporate, municipal, or government bonds.

This group of funds invest, on average, $47.91 \%$ of its funds in common stocks in improving periods versus $52.72 \%$ in worsening periods. This difference is statistically significant $(\mathrm{p}<0.0001)$. The group's average investment in "other securities" is $6.215 \%$ in improving periods versus $7.919 \%$ in worsening periods. This difference is also statistically significant $(\mathrm{p}<0.0001)$.

The group invests, on average, $10.046 \%$ of its funds in corporate bonds in improving periods versus $8.808 \%$ in worsening periods. This difference is statistically significant $(\mathrm{p}<0.0001)$. The group invests, on average, $17.908 \%$ of its funds in municipal bonds in improving periods versus $14.821 \%$ in worsening periods. This difference is also statistically significant $(\mathrm{p}<0.0001)$. The group invests, on average, $8.562 \%$ of its funds in government bonds in improving periods versus $7.002 \%$ in worsening periods. This difference is also statistically significant $(\mathrm{p}<0.0001)$.

The group's average investment in warrants is $0.031 \%$ in improving periods versus $0.026 \%$ in worsening periods. This difference is statistically significant $(\mathrm{p}=0.0491)$. The group holds, on average, $8.234 \%$ of its funds in cash in improving periods versus $7.624 \%$ in worsening periods. This difference is also statistically significant $(\mathrm{p}=0.0039)$.

The 1- and 2-star groups alter their investments significantly in only 3 and 2 asset classes, respectively. Both the 3- star and the 5-star groups make significant changes in 4 asset classes.

In improving periods, the 1-star group has a higher percentage of their money invested in preferred stock and warrants. They also hold less cash during improving periods. The group's average investment in preferred stock is $0.364 \%$ in improving periods versus $0.358 \%$ in worsening periods. This difference is statistically significant $(\mathrm{p}=0.0351)$. The group's average investment in warrants is $0.033 \%$ in improving periods versus $0.021 \%$ in worsening periods. This difference is also statistically significant $(\mathrm{p}=0.0002)$. The group holds, on average, $15.708 \%$ of its funds in cash in improving periods versus $16.411 \%$ in worsening periods. This difference is also statistically significant $(\mathrm{p}=0.0002)$.

In improving periods, the 2-star group has a higher percentage of their money invested in preferred stock and municipal bonds. The group's average investment in preferred stock is $0.261 \%$ in improving periods versus $0.245 \%$ in worsening periods. This difference is statistically significant $(\mathrm{p}=0.0176)$. The group's average investment in municipal bonds is $12.551 \%$ in improving periods versus $12.247 \%$ in worsening periods. This difference is also statistically significant $(\mathrm{p}=0.0704)$.

In improving periods, the 3-star group has a higher percentage of their money invested in common stock and warrants, and a lower percentage of their money invested in corporate and government bonds. The group's average investment in common stock is $50.834 \%$ in improving periods versus $49.284 \%$ in worsening periods. This difference is statistically significant $(\mathrm{p}<0.0001)$. The group's average investment in warrants is $0.022 \%$ in improving periods versus $0.017 \%$ in worsening periods. This difference is also statistically significant $(\mathrm{p}=0.0622)$. The group's average investment in corporate bonds is $6.882 \%$ in improving periods versus $7.017 \%$ in worsening periods. This difference is statistically significant $(\mathrm{p}=0.0458)$. The group's average investment in government bonds is $7.091 \%$ in improving periods versus $7.671 \%$ in worsening periods. This difference is also statistically significant $(\mathrm{p}=0.0851)$.

In improving periods, the 5-star group has a higher percentage of their money invested in common stock and warrants, and a lower percentage of their money invested in corporate or municipal bonds. The group's average investment in common stock is 59.538\% in improving periods versus only 55.049\% in worsening periods. This difference is statistically significant $(\mathrm{p}<0.0001)$. The group's average investment in warrants is $0.030 \%$ in improving periods versus only $0.026 \%$ in worsening periods. This difference is also statistically significant $(\mathrm{p}=0.0858)$. The group's average investment in corporate bonds is only $7.933 \%$ in improving periods versus 7.961 in worsening periods. This difference is also statistically significant $(p=0.0049)$. The 
group's average investment in municipal bonds is only 9.455\% in improving periods versus $12.038 \%$ in worsening periods. This difference is also statistically significant $(\mathrm{p}<0.0001)$.

How is the behavior of the 4-star and the 5-star groups across improving versus worsening periods? During the improving business condition periods, the 5 -star group significantly increases its investments in common stocks and warrants, and significantly reduces its investments in corporate and municipal bonds (makes sense!) when compared to the worsening condition periods. On the other hand, during the improving business condition periods, the 4-star group reduces its investments in common stocks while increasing its investments in corporate bonds, municipal bonds, government bonds and cash (wrong direction!) when compared to the worsening business condition periods. This explains the lower star rating of 4-star funds although the general composition of this group's investments (the weights in each asset class) are somewhat similar to the 5-star funds.

How do the other star-groups act during improving versus worsening business condition periods? During the improving business condition periods, the 1-star funds have increased their investments in preferred stocks and warrants and have reduced their cash holdings, but these are small portions of their total investments. They didn't alter their investments in big asset classes like common stocks and bonds, therefore they suffered. During the improving business condition periods, the 2-star funds have increased their investments in preferred stocks and municipal bonds. However, there was no significant change in their investments in big asset classes, therefore they suffered as well. Finally, during the improving business condition periods, the 3star funds have increased their investments in common stocks by just $1 \%$ and have reduced their investments in corporate bonds and government bonds. So, they did alter their investments in a few main asset classes.

Table 4 shows the NAVs across Improving versus Worsening Periods. The last column shows the results of the Wilcoxon test. Only the 5-star funds have significantly increased their NAVs in Improving Periods. For this group, the median value of NAV is $\$ 14.33$ in improving periods versus $\$ 14.12$ in worsening periods. This difference is statistically significant ( $\mathrm{p}=0.0143$ ). Interestingly, all other groups have actually lower NAVs in Improving Periods when compared to Worsening Periods.

Table 4. NAVs in Improving vs. Worsening Periods

\begin{tabular}{|l|c|c|c|c|c|c|c|}
\hline & & \multicolumn{2}{|c|}{ Improving } & & \multicolumn{2}{c|}{ Worsening } & Wilcoxon \\
\hline & $\mathbf{N}$ & Mean & Median & $\mathbf{N}$ & Mean & Median & p-value \\
\hline 1-star & 10,045 & 11.73 & 10.36 & 10,507 & 12.24 & 10.49 & $<0.0001$ \\
\hline 2-star & 19,702 & 12.41 & 10.84 & 20,473 & 12.92 & 11.10 & $<0.0001$ \\
\hline 3-star & 44,245 & 13.00 & 11.06 & 44,262 & 13.41 & 11.22 & $<0.0001$ \\
\hline 4-star & 17,410 & 15.48 & 12.18 & 19,138 & 16.26 & 12.73 & $<0.0001$ \\
\hline 5-star & 6,746 & 18.02 & 14.33 & 7,639 & 17.69 & 14.12 & 0.0143 \\
\hline
\end{tabular}

Source: Authors' own work.

The 1-star group had a median NAV of $\$ 10.36$ in improving periods versus $\$ 10.49$ in worsening periods. This difference is statistically significant $(\mathrm{p}<0.0001)$. The 2 -star group had a median NAV of $\$ 10.84$ in improving periods versus $\$ 11.10$ in worsening periods. The difference is also statistically significant $(p<0.0001)$. The 3star group had a median NAV of $\$ 11.06$ in improving periods versus $\$ 11.22$ in worsening periods. The difference is statistically significant $(\mathrm{p}<0.0001)$. The 4-star group had a median NAV of $\$ 12.18$ in improving periods versus $\$ 12.73$ in worsening periods. The difference is also statistically significant $(\mathrm{p}<0.0001)$.

These results indicate that the 5-star funds are generally successful in their investments and their investments are more in line with the macro-economy (i.e. they have more money in riskier assets when business conditions are improving and have more money in less risky assets when business conditions are worsening), therefore this success is reflected in their net asset values.

\section{Conclusion}

In this study, we show in detail how star ratings are related to the general investment composition of the funds as well as to the funds' behavior across "improving" versus "worsening" business condition periods.

Among the five groups of star ratings, the 5-star funds' investment in risky assets like common stocks and preferred stocks is the highest. Among the five groups of star ratings, the 5-star funds' investment in the least risky assets like government bonds is the lowest (in cash, it is the second lowest). In terms of convertible 
bonds and corporate bonds, the 5-star funds have the second highest investment after the 4-star funds. In terms of municipal bonds, the 4 -star group has the biggest investment.

Our results show that the 5-star and the 4-star fund groups are similar in their investments except for the following: The 5-star funds generally invest more in common and preferred stocks, and the 4-star funds invest more in bonds (convertible, corporate, municipal, and government bonds).

Our results show that Net Asset Values (NAVs) gradually increase with the star rating. The 1-star funds' average NAV is $\$ 11.99$. The 2-star, 3-star, 4-star, and 5-star funds' average NAV is $\$ 12.67, \$ 13.21, \$ 15.89$, and $\$ 17.84$, respectively.

When we examine how each group's investments change across "improving" versus "worsening" business condition periods, we find that the 4-star group is the most aggressive among the five groups. This group changes its investments across "improving" and "worsening" periods in seven out of nine asset classes. The 1 - and 2-star groups alter their investments significantly in only 3 and 2 asset classes. Both the 3- star and the 5 -star groups make significant changes in 4 asset classes.

Our results show that the behavior of the 4-star and 5-star groups across "improving" versus "worsening" periods differ in many ways: During "improving" periods, the 5-star group significantly increases its investments in common stocks and warrants, and significantly reduces its investments in corporate and municipal bonds (which makes sense). The 4-star group reduces its investments in common stocks while increasing its investments in corporate bonds, municipal bonds, government bonds and cash (which is the wrong action). This explains the lower star rating of the 4-star funds although the general composition of the group's investments (the weights in each asset class) is somewhat similar to the 5-star funds.

During "improving" periods, the 1-star funds, on average, increase their investments in preferred stocks and warrants and reduce their cash, but these are small portions of their total investments. They do not alter their investments in big asset classes like common stocks and bonds, therefore they tend to suffer in terms of both NAVs and star ratings.

During "improving" periods, the 2-star funds, on average, increase their investments in preferred stocks and municipal bonds. They do not significantly change their investments in big asset classes, therefore they tend to suffer as well.

During "improving" periods, the 3-star funds, on average, increase their investments in common stocks by only one percent and reduce their investments in corporate bonds and government bonds. So, they do alter their investments in a few main asset classes. Therefore, they do not suffer as much as the 1-star and the 2star groups in terms of NAVs and star ratings.

Our results also show that only the 5-star funds have significantly increased their NAVs during "improving" periods. Interestingly, all other groups have actually significantly reduced their NAVs during "improving" periods when compared to "worsening" periods.

We can conclude that the 5-star funds tend to invest more in riskier assets and they tend to better adjust to the conditions (i.e. invest more in common stocks and less in bonds in improving periods) when compared to the other groups. This explains their success: higher NAVs and higher star ratings compared to the other groups.

This study shows that mutual funds' star ratings and NAVs are linked to these funds' success in their adaptation to the macro-economic environment. We document that the lower-rated funds are not making the necessary changes in their investments (i.e. especially in the main asset classes like stocks and bonds) when the economy is improving or worsening.

\section{References}

1. Avramov, D. (2004). Stock return predictability and asset pricing models. The Review of Financial Studies, 17, 699-738. https://academic.oup.com/rfs/article-abstract/17/3/699/1612990.

2. Avramov, D., and Chordia, T. (2006). Predicting stock returns. Journal of Financial Economics, 82(2), 387-415. https://www.sciencedirect.com/science/article/abs/pii/S0304405X06001449.

3. Avramov, D., and Wermers, R. (2006). Investing in mutual funds when returns are predictable. Journal of Financial Economics, 81(2), 339-377. 
https://www.sciencedirect.com/science/article/abs/pii/S0304405X06000031.

4. Bello, Z. Y. (2008). The performance of US domestic equity mutual funds during recent recessions. Global Journal of Finance and Banking Issues, 3(2). https://papers.ssrn.com/sol3/papers.cfm?abstract $\mathrm{id}=1536156$

5. Brinson, G. P., Hood, L. R., and Beebower, G. L. (1995). Determinants of portfolio performance, Financial Analysts Journal, 51(1), 133-138. https://pfa.kz/images/download/100331brinson_Determinants_Portfolio_Performance.pdf

6. Carhart, M. M. (1997). On persistence in mutual fund performance. The Journal of Finance, 52(1), 57 82. https://onlinelibrary.wiley.com/doi/full/10.1111/j.1540-6261.1997.tb03808.x

7. Cederburg, S. (2008). Mutual fund investor behavior across the business cycle, Available at SSRN 1107014. https://papers.ssrn.com/sol3/papers.cfm?abstract_id=1107014

8. Cici, G. (2010). The relation of the disposition effect to mutual fund trades and performance, Available at SSRN 645841. https://papers.ssrn.com/sol3/papers.cfm?abstract_id=645841

9. Fink, C., Raatz, K., and Weigert, F. (2015). Do Mutual Funds Outperform During Recessions? International (Counter-) Evidence. International (Counter-) Evidence (September 28, 2014), University of St. Gallen, School of Finance Research Paper, (2014/15). https://papers.ssrn.com/sol3/papers.cfm?abstract id $=2497680$

10. Fortin, R., and Michelson, S. (2002). Indexing versus active mutual fund management. Journal of Planning-Denver, 15(9),

82-95. https://www.researchgate.net/profile/Stuart_Michelson/publication/242078804_Indexing_Versus_Activ e_Mutual_Fund_Management/links/0046353c557a42ae39000000.pdf

11. Glode, V. (2011). Why mutual funds "underperform". Journal of Financial Economics, 99(3), 546-559. https://www.sciencedirect.com/science/article/abs/pii/S0304405X10002448

12. Glode, V., Hollifield, B., Kacperczyk, M. T., and Kogan, S. (2012). Time-varying predictability in mutual fund returns, Available at SSRN 1364351. https://papers.ssrn.com/sol3/papers.cfm?abstract_id=1364351

13. Jank, S. (2012). Mutual fund flows, expected returns, and the real economy. Journal of Banking and Finance, 36(11), 3060-3070. https://www.sciencedirect.com/science/article/abs/pii/S0378426612001732

14. Kacperczyk, M., Nieuwerburgh, S. V., and Veldkamp, L. (2014). Time-varying fund manager skill. The Journal of Finance, 69(4), 1455-1484. https://onlinelibrary.wiley.com/doi/abs/10.1111/jofi.12084

15. Kacperczyk, M., Nieuwerburgh, S. V., and Veldkamp, L. (2016). A rational theory of mutual funds' attention allocation. $\quad$ Econometrica, $54(2), \quad$ 571-626. https://onlinelibrary.wiley.com/doi/abs/10.3982/ECTA11412

16. Kandel, S., and Stambaugh, R. (1996). On the Predictability of Stock Returns: An Asset Allocation perspective. Journal of Finance, 51, 385-424. https://onlinelibrary.wiley.com/doi/abs/10.1111/j.15406261.1996.tb02689.x

17. Kosowski, R. (2011). Do mutual funds perform when it matters most to investors? US mutual fund performance and risk in recessions and expansions. The Quarterly Journal of Finance, 1(03), 607-664. https://www.worldscientific.com/doi/abs/10.1142/S2010139211000146

18. Lynch, A. W., Wachter, J. A., and Boudry, W. (2002). Does mutual fund performance vary over the business cycle? AFA 2004 San Diego Meetings. https://papers.ssrn.com/sol3/papers.cfm?abstract_id=470783

19. Wermers, R. (2000). Mutual fund performance: An empirical decomposition into stock-picking talent, style, transactions costs, and expenses. The Journal of Finance, 55(4), 1655-1695. https://onlinelibrary.wiley.com/doi/abs/10.1111/0022-1082.00263 